\title{
A Cost Model for Broadband Access Networks: FTTx versus WiMAX
}

\author{
João Paulo Ribeiro Pereira \\ ESTiG - IPBragança - Portugal \\ jprp@ipb.pt
}

\begin{abstract}
Local communities and governments are taking various steps to fight the so-called "digital divide" between well served urban communities and undeserved areas. In order to make broadband access available to these under served areas, several technical solutions are available with the capacity to provide high speed Internet access, video, telephony services, etc. This paper presents a cost-model and a tool for the evaluation of broadband access technologies (xDSL, HFC, FTTX, WiMAX, PLC and satellite), and compares two technologies: FTTX and WiMAX. Our tool compares these different access technologies in different scenarios, and examining the capital expense and deployment of building access networks with the same requisite performance using each technology. The cost model is limited to the access part of the network. The results obtained by our evaluation tool give the possibility to compare several BB access technologies, and support the decision about which is the better technological solution for a given scenario
\end{abstract}

\section{Introduction}

Until few years ago, Internet access for residential users was almost exclusively made via the public switched telephone networks (PSTN) over the twisted copper pair [1]. The new services requirements demand high speed broadband access and led to the development of several last-mile solutions (xDSL, HFC, FTTx, PLC, FWA, Satellite...) capable to support the services that Internet has to offer.

Access to ICT as a development tool for society is recognized as a political, economic and social issue of high importance. Lisbon 2010 Strategy defines that the access to the eGovernment, eHealth, eLearning, eBusiness services will be essential and must become ubiquitous across Europe. Ubiquitous broadband access will require a minimum bit rate that must be high enough to allow all citizens to benefit from these services. This minimum bit rate should be at least 2 Mbps with the need to evolve to speeds which will be two to four times higher as new applications and usage develops over the next five to ten years. Entertainment services will be the main driver for moving to higher bit rates [2]. With the growing demand for new broadband services, the network operators are facing increasing bandwidth requirements. To deliver the new services to end customers is required new infrastructures and equipment.

However, the pre-existing telecommunications infrastructure is generally poor and unevenly distributed in favor of urban centers [3]. In most rural areas low population density and high deployment costs discourage private investments, creating a negative feedback of limited capacity, high prices, and low service demand. Building telecommunications networks in rural areas is costly and in many cases there is not a good commercial business case for rural deployments. While established and competitive service providers already offer solutions for urban and suburban areas, there is little or no commitment to connect areas that include smaller towns and rural villages [4].

\section{Technical solutions to access networks}

In general, broadband access technologies can be classified by the physical medium in two major groups, namely [5]:

Wired (or fixed line) technologies: The fixed line solutions communicate via a physical network that provides a direct "wired" connection from the customer to the service supplier. Some authors divide the wired technologies in Copper-based and fiber-based.

Wireless technologies: Wireless solutions use radio or microwave frequencies to provide a connection between the customer and the operator's network. Wireless access technologies can be generally classified into three categories [6]: fixed terrestrial (fixed wireless access - FWA), mobile terrestrial (mobile wireless access - MWA), and satellite (nomadic wireless access- NWA).The fixed terrestrial 
wireless access is a wireless technology to replace the use of copper or coaxial cables in the local loop.

The choice of access technology depends on various variables like demography and geography. Others important variables are [7]: Number of subscribers; Clients dispersion and service area; Existing infrastructures; Network architecture (Wireline, Wireless or hybrid); Services to support (like voice, data and video) and associated bit rate; Geographic characteristics; Infrastructure costs; Labor cost; Operation costs; and Access costs.

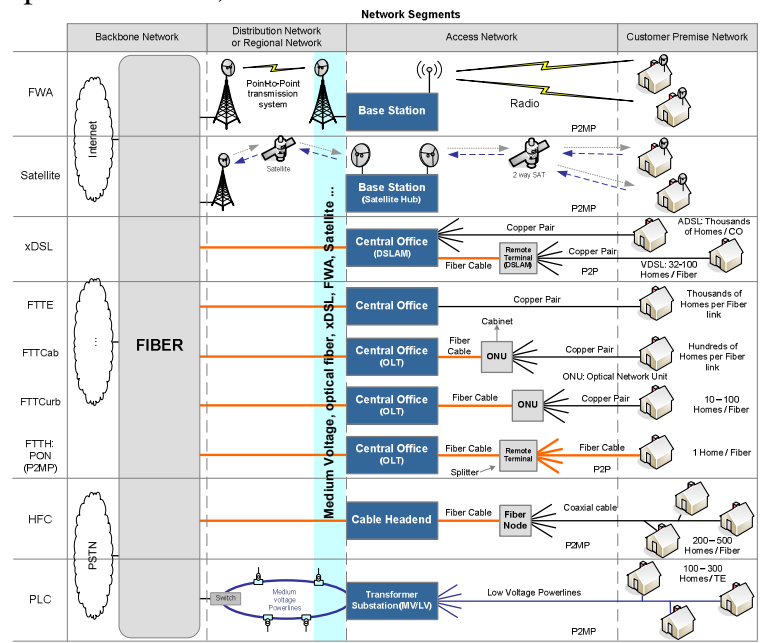

Figure 1: Broadband Access Network Technologies

\section{Techno-economic Framework and Model Description}

As we have see above, there are a many competing technologies which can provide the bandwidth required to deliver broadband services, but each technology has its limits in terms of bandwidth, reliability, cost or coverage. At present no single technology or network architectures seems the obvious choice. Our tool compares these different access technologies in different scenarios, and examining the capital expense and deployment of building access networks with the same requisite performance using each technology. The cost model is limited to the access part of the network.

Access network refers to the network between the Distribution / Regional network and the subscriber. The local access network is also often referred to as "the last mile" and "the local loop". The access network remains a bottleneck in terms of the bandwidth and service quality it affords the end user. The last mile problem has impeded the growth of broadband services and applications. The access network is much more spread geographically and covers larger areas. The available capacity on access lines is modest with respect to availability in aggregation/distribution and core parts of the network [5]. The capacity of the access network to delivery broadband services remains as a challenge ("last mile problem").

Then, this part of the network is usually the most expensive component in terms of capital investment and operation, administration and maintenance costs (OAM cost). Some studies reefer that this networks required $70 \%$ of the total investment [8]. The inadequacy of the access link (bottleneck problem) is particularly felt when the user require applications and services likely to become popular in the future. Interactive video applications, interactive gaming, video telephony, videoconferencing, remote storage, virtual DVD, and high-speed virtual private networks (VPNs) between geographically separated office locations or between homes and office locations for telecommuters are just a few such applications.

Our model framework defines the network starting from a single central office (or headend, transformer substation, base station, etc.) node and ending at a subscriber CPE. At the Access Node, we consider only the devices that support the connection to the access network: OLT, DSLAM, CMTS, etc. The equipment beyond the Access Node doesn't include, and in the subscriber side, our network goes to modem equipment. The tool implements a methodology for the techno-economic analysis of access networks for residential customers.

The structure of a network depends on the nature of the services offered and their requirements including: bandwidth, symmetry of communication, and expected levels of demand. The techno-economic framework basically consists of the following building blocks [9]:

- Area definition: geography and existing network infrastructure situation.

- Service definitions for each user segment with adoption rates and tariffs.

- Network dimensioning rules and cost trends of relevant network equipment.

- Cost models for investments (CAPEX) and operation costs (OPEX).

- Discounted cash flow model.

- Output metrics to be calculated.

\subsection{Cost Model}

The network architectures and technologies will vary by cost, risk, flexibility, scalability, complexity and time to market considerations. It was argued in that the most critical parameters to include in a technoeconomical model for broadband systems are subscriber density, civil works configuration, component cost evolution, and demand assessment (service penetration). 
The model analyzes several technical parameters (distances, bandwidth, equipment performance, etc.) and economic parameters (equipment costs, installation costs, service pricing, demographic distribution, etc.). The model simulates the evolution of the business for 10 years. This means that each parameter can have a different value each year, which can be useful for reflecting factors that evolve with time: Cost reductions, productivity increases, etc [10].

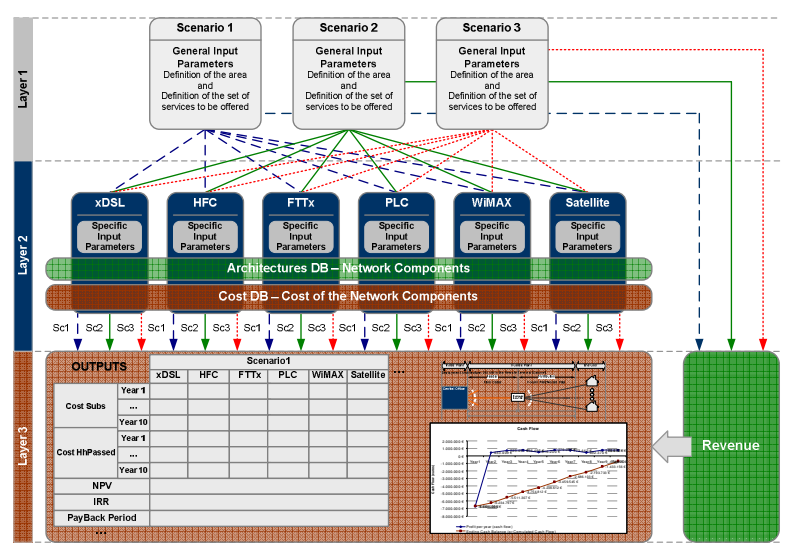

Figure 2: Tool Architecture (layers)

There are different network architectures that provide varied levels of service to the customer. Each architecture varies in complexity, network functionality, services supported and overall network costs. The model framework illustrated in Figure 2 is the basis of our tool. The tool has three main layers: General Input parameters (Layer 1); Specific Input parameters and Processing (Layer 2) and Outputs (Layer3).

\section{General Model Assumptions}

Access networks (Wired technologies) have two separate but related components [11]: Physical plant and Network equipment. The physical plant includes the locations where equipment is placed and the connections between these locations. These physical plant costs depend primarily on the labor and real estate costs associated with the network service area, rather than on the specific technology being deployed

\begin{tabular}{|l|l|l|}
$\begin{array}{l}\text { Network } \\
\text { Component }\end{array}$ & $\begin{array}{l}\text { Component } \\
\text { Costs }\end{array}$ & Description \\
\hline $\begin{array}{l}\text { Physical Plant } \\
\text { component } \\
\text { costs }\end{array}$ & Housing & $\begin{array}{l}\text { The housing cost is the cost of building } \\
\text { any structures required (e.g., remote } \\
\text { terminal huts and CO buildings), and } \\
\text { includes the cost of permits, labor, and } \\
\text { materials. }\end{array}$ \\
\cline { 2 - 3 } & Cabling & $\begin{array}{l}\text { The cabling cost is the cost of the } \\
\text { materials (i.e., the cost of the necessary } \\
\text { fiber optic or twisted pair cables). }\end{array}$ \\
\cline { 2 - 3 } & Trenching & $\begin{array}{l}\text { The trenching cost is the cost of the } \\
\text { labor required to install the cabling } \\
\text { either in underground ducts (buried }\end{array}$ \\
\hline
\end{tabular}

\begin{tabular}{|l|l|l|}
\hline \multirow{3}{*}{$\begin{array}{l}\text { Network } \\
\text { Equipment }\end{array}$} & $\begin{array}{l}\text { Equipment } \\
\text { needed } \\
\text { between CO } \\
\text { and CPE }\end{array}$ & $\begin{array}{l}\text { trenching) or on overhead poles (aerial } \\
\text { trenching). }\end{array}$ \\
\cline { 2 - 3 } & $\begin{array}{l}\text { The electronic switches and/or optical } \\
\text { devices (e.g., splitters) needed to carry } \\
\text { the traffic over the physical plant. }\end{array}$ \\
\hline Equipment & $\begin{array}{l}\text { The price and other properties of the } \\
\text { Access node, as well as the nature of } \\
\text { the CPE unit, depend strongly on the } \\
\text { access technology. }\end{array}$ \\
\hline
\end{tabular}

Table 1: General Model Assumptions

The deployment cost calculations assumptions, assume that all construction work required to provide service to all homes passed takes place during the first year (deployment phase). However, only enough electronics are deployed in the $\mathrm{CO}$ and remote terminal to accommodate the initial assumption for the take rate [12]. The construction work includes all of the equipment necessary for fiber management, building of aggregation points and enclosures, and the running of fiber to all homes.

\section{Input Requirements}

To build a new network or upgrading an existing one, an operator has a set of technologies to choose. The cost structure may vary significantly from one technology to the other in terms of up-front costs, variable cost and maintenance costs.

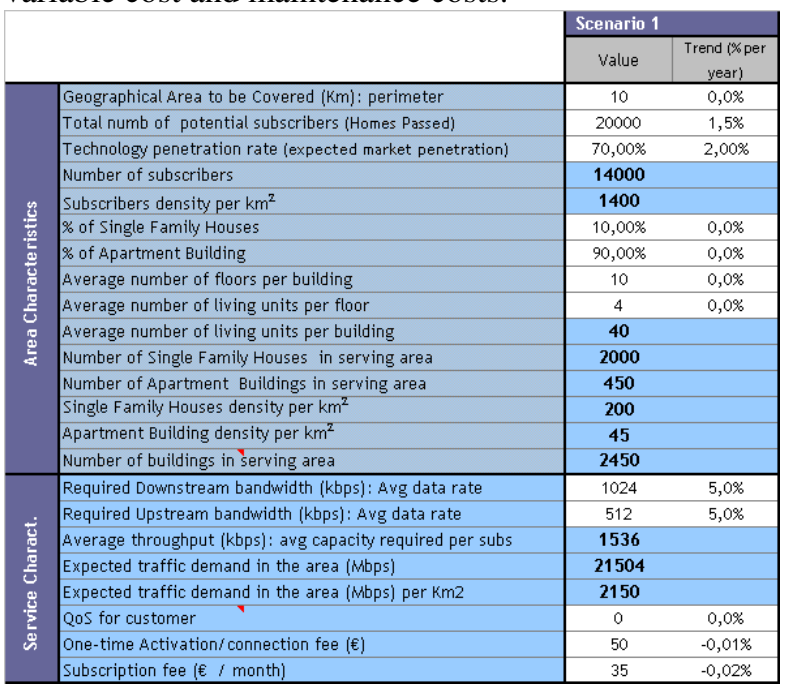

Table 2: Generic Input Parameters

Each technology type has elements that are dedicated as for example modems and shared elements (shared by many users) such as cabinets, optical network units, base stations and cables.

A number of choices, assumptions, and predictions have to be made before proceeding to the technoeconomic analysis of a broadband access network. These include the selection of the geographical areas and customer segments to be served, the services to be 
provided, and the technology to be used to provide the services [13].

As we have seen above, the definition of the Input attributes is fundamental to obtain the right outputs. Then, we define three main activities: Area Definition, Requested Services, and Type of Access.

\begin{tabular}{|c|c|}
\hline Main Blocks & Description \\
\hline $\begin{array}{lr}\text { Area } & \text { Description } \\
\text { and } & \text { Potential } \\
\text { Market } & \end{array}$ & $\begin{array}{l}\text { The area definition: Selection of the geographical area; } \\
\text { Customer segments to be served; and Existing network } \\
\text { infrastructure situation }\end{array}$ \\
\hline $\begin{array}{l}\text { Definition of the } \\
\text { set of services to } \\
\text { be offered } \\
\text { (Requested } \\
\text { Services): }\end{array}$ & $\begin{array}{l}\text { We divide these parameters in two main categories: } \\
\text { a) Commercial parameters: Installation fee charged to } \\
\text { new customer; Monthly fee charged to customers; and } \\
\text { Churn rate (It is the percentage of existing users that } \\
\text { discontinue their subscription every year. In our } \\
\text { model, this is dependent on the perceived quality of } \\
\text { the service provided to customers), and } \\
\text { b) Service parameters: Bandwidth included in the SLA } \\
\text { (service level agreement); QoS for customers; and } \\
\text { Concurrency factor during peak hour for residential } \\
\text { users. }\end{array}$ \\
\hline $\begin{array}{l}\text { Selection of the } \\
\text { architecture/techn } \\
\text { ology to be used } \\
\text { (Type of Access) }\end{array}$ & $\begin{array}{l}\text { The selection of the architecture/technology to be used } \\
\text { to provide the selected services (Type of Access): } \\
\text { Network architecture and technologies; Cost of } \\
\text { network equipment and installation; Cost of operation, } \\
\text { administration, and maintenance procedures. }\end{array}$ \\
\hline
\end{tabular}

Table 3: Input Parameters Classification

\section{Output Results}

The financial analysis requires from the tool several outputs. The financial analysis is basically focused on these steps [10]: Compute the amount of equipment that needs to be installed each year for providing the service; Compute the amount of money spent on operational costs (Operations and Maintenance, Customer Support, Service Provisioning, Marketing); Compute the income for each year, taking into account that existing customers pay 12 months, while new customers pay an average of 6 months during their first year; Compute the net profit obtained each year; and Compute the NPV (Net Present Value) of the yearly profits.

Then, the outputs calculated are: CAPEX; OPEX; Subscriber costs; ARPU: Average Revenue Per User; Cost per subscriber; Cost per home passed; Mbps cost; OAM costs; Installation cost; Net Present Value (NPV); Internal Rate of Return (IRR); Payback Period; Revenues; Investments; Life Cycle Cost; Cash balance.

\section{FTTx technology}

FTTx is a generic term for those technologies which bring fiber, a step closer to the subscriber. Today, fiber networks come in many varieties, depending on the termination point (depending on where the PON terminates): The system can be described as a fiber-tothe-home (FTTH), fiber-to-the-building (FTTB), fiberto-the-curb (FTTC), or fiber-to-the-cabinet (FTTCab) system (see next figure). When fiber is run all the way to the residence, the design is called fiber to the home
(FTTH). If a single fiber serves a few households, the design is called fiber to the curb. FTTC refers to a telecommunications network where fiber extends to the curbs close to homes and businesses.

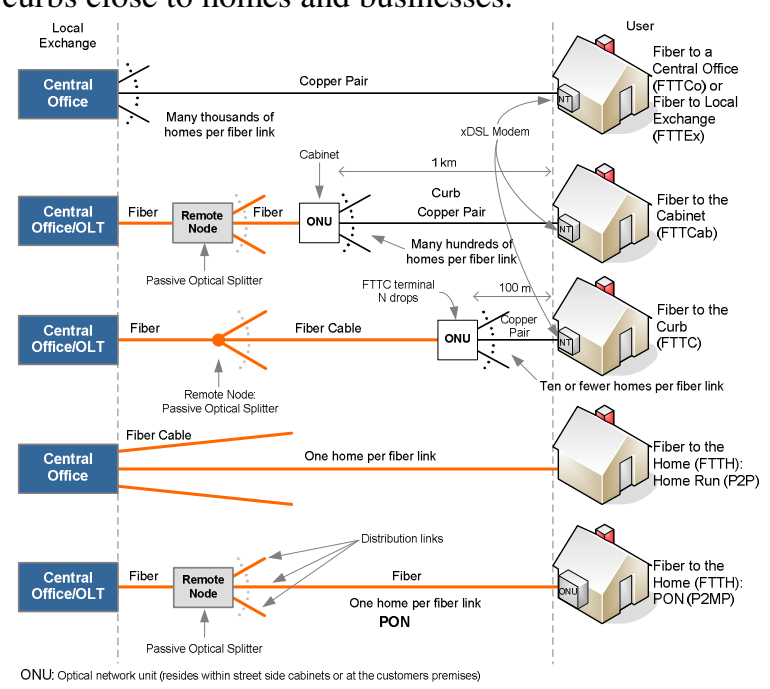

Figure 3: FTTx Technologies

This technology brings fiber from the local exchange (central office) down to a node in the access network or to the curb, where equipment is housed in a street cabinet to convert signals from optical to electronic. Coaxial or twisted pair copper cable then is used to carry data into the buildings. For simplicity, most people have begun to refer to the fiber network as FTTx, in which $\mathrm{x}$ stands for the termination point.

\subsection{Cost Modeling the FTTx System}

In our analysis, we only consider three of the FTTx technologies: FTTh: PON; FTTcurb; and FTTcabinet. Like VDSL and HFC, the outside plant is divided into Feeder, Distribution and Drop (see Figure). The architecture for this technology considers that the outside plant have two layers of split (Primary and secondary split).

For example if the primary split is $1 \times 4$ and the secondary split is $1 \times 8$, then the network splitting ratio (or split scenario) will be 32 . This means that a single feeder network support 32 subscribers. As we can see in above figure, the total costs of the FTTx technologies are dependent of three main areas: Inside plant; Outside plant; and CPE.

In the local exchange (or central office), the OLT (Optical Line Termination) ensures the interface between the switching equipment and the ODN (Optical Distribution Network).The OM (Optical Monitoring) module of which the functionality is to survey the ODN quality and an MDF (Main Distribution Frame) which provides a connection point 
between equipment and outside cables. For outside plant construction, it is necessary to consider the hardware parts (cables, splices, splitters, connectors and enclosures) together with civil work and installation techniques. The optical network terminates at the ONU (Optical Network Unit) whose location depends on the chosen architecture.

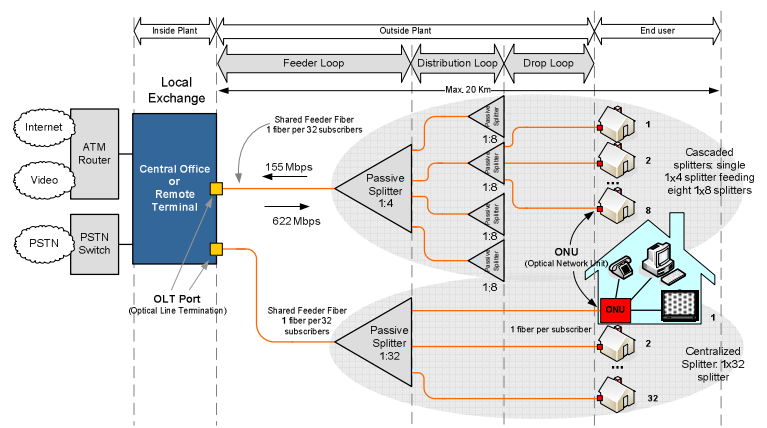

Figure 4: FTTH: PON Architecture

Finally, powering equipment is needed to supply all active equipment.

Model includes the following cost drivers: Optical cable costs: Feeder, distribution, drop, cable assemblies, etc; Passive hardware \& equipment costs: Couplers/Splitters, connectors, enclosures, splice closures, racks/trays/cassettes, etc; and Installation \& labor costs: Cable prep \& installation, hardware installation, splicing, termination, etc.

The costs of digging and ducting are the major cost items in access networks, outweighing by far the costs of the transmission medium and the line terminating equipment. Civil works typically may take some $85 \%$ of Fiber to the Home (FTTH) first installed network costs, while the fiber cable and the optical components take only 3\%; the remainder is taken by other hardware, installation activities, and other services. Hence in green-field situations the costs of introducing FTTH may not differ much from e.g. twisted copper pair or coaxial cable access solutions [14].

\subsection{FTTx Equipment Costs}

The cost of a PON deployment varies widely because of the high-price of the OLT, the large number of ONUs that are required to make the OLT deployment economical, and the limited geographic coverage of the ONU serving area [15].

Optical Line Terminal (OLT): Located in the central office. The OLT is like a switch that provides service to the end users as well as handling QoS issues, service level agreements (SLAs) and other tasks. The OLT will also deal with multiplexing data from different users into the fiberoptic.
Optical Network Unit (ONU): The ONUs are simple devices that receive the traffic in an optical form and convert it to the client's desired protocol (ATM, Ethernet etc). Several ONUs can be aggregated back to a single OLT. Resides within street side cabinets or at the customer's premises and works under the control of OLT to implement transmission protocol. Can be configured in FTTC, FTTB and FTTH configurations.

Splitter: Depending upon optical splitter placement, various portions of outside plant (OSP) resources (fiber material and splicing costs) may also be shared among multiple users. By increasing the sharing of OSP resources, certain splitter architectures decrease the OSP per-user cost.

\section{WiMAX technology}

Wireless technologies can be broadly categorized into those requiring line of sight (LOS) and those that do not [16]: Line of sight (LOS): Point-to-point microwave, Local Multipoint Delivery System (LMDS), Free Space Optics (FSO), and Broadband Satellite all require line-of-sight for reliable signal transmission Non-line of sight (NLOS): GSM, CDMA, 3G, WiFi, WiMAX (Worldwide Interoperability for Microwave Access), and fixed wireless broadband technologies like Multipoint Multichannel Distribution System (MMDS) require no line-of-sight between the transmission hub and receiving equipment.

Line of sight means that there is an unobstructed path from the CPE antenna to the access point antenna. If the signal can only go from the CPE to the access point by being reflected by objects, such as trees, the situation is called non-line of sight. NLOS systems are based on Orthogonal Frequency Division Multiplexing (OFDM), which combats multipath interference, thereby permitting the distance between the CPE and the access point to reach up to 50 kilometers in the MMDS band. However, NLOS systems are more expensive than LOS systems [1].

Fixed Wireless Access (FWA) is specifically designed to be an alternative to a wired Access network. Local Multipoint Distribution System (LMDS), WiFi and WiMAX are fixed wireless broadband Access systems for the fixed network. However, the LMDS system did not succeed, because of too expensive components and too low production volumes [17]. The new fixed wireless broadband access systems (WiFi and WiMAX) are now in a similar position. Especially WiMAX has the possibility either to give high capacity or to have a long reach. The system may be an interesting technology in areas not covered by DSL technology. 


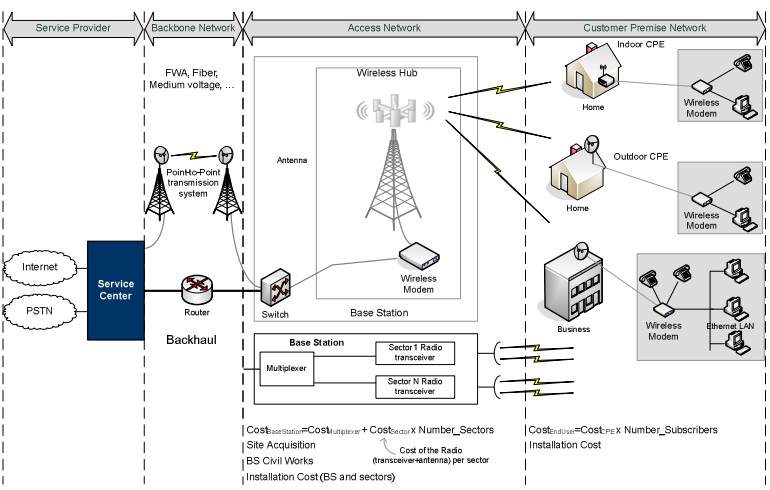

Figure 5: FWA network architecture (PMP)

The original WiMAX standard, IEEE 802.16, uses the bands in the 10 to $66 \mathrm{GHz}$ range. $802.16 \mathrm{a}$, updated in 2004 to 802.16-2004, added support for the 2 to 11 $\mathrm{GHz}$ range, of which many parts are already worldwidely stated as license free. For this purpose, most business interest is expected to concentrate in the 802.16-2004 standards. The WiMAX specification overcomes many of the limitations of Wi-Fi (IEEE 802.11 ) by providing increased bandwidth efficiency and stronger encryption. Broadband FWA systems operating at $3.5 \mathrm{GHz}$ or above, e.g. WiMAX will provide better QoS than $\mathrm{WiFi}$ at $2.5 \mathrm{GHz}$. Although BFWA CPE costs are relatively high, they are expected to fall as the technology matures and standardized systems become well established. With a reach of up to $35 \mathrm{~km}$ for $3.5 \mathrm{GHz}$ and higher frequencies, BFWA systems are able to serve larger geographic areas of operation than WiFi. It also aims to provide connectivity without requiring direct line of sight (LOS) under certain circumstances. A sample 802.16 configuration for fixed Internet Access provision is shown in Figure.

As we see above, WiMAX uses OFDM in the RF front-end, which is robust in adverse channel conditions and enables NLOS operation. This feature simplifies installation issues and improves coverage, while maintaining a high level of spectral efficiency. Modulation and coding can be adapted per burst, ever striving to achieve a balance between robustness and efficiency in accordance with prevailing link conditions [18]. One of the principal advantages of this technology is the capacity to deploy broadband services in large areas without physical cables. These characteristics give to telecommunication supplier the capacity to implement new broadband telecommunication infrastructures very quickly, and with a lower cost than the wired networks.

\begin{tabular}{|l|l|}
\hline Typical max. coverage & $12 \sim 15 \mathrm{~km}(\mathrm{LOS}), 1 \sim 2 \mathrm{~km}$ (NLOS) \\
Architecture & $\begin{array}{l}\text { Central end - Base Station } \\
\text { Subscriber - Subscriber Station } \\
\text { PTP, PTMP and mesh topologies }\end{array}$ \\
\hline Bit Rate (max.) & $\begin{array}{l}\text { BS }-70 \mathrm{Mb} / \mathrm{s}(\text { bandwidth } 14 \mathrm{MHz}), 100 \mathrm{MB} / \mathrm{s} \\
\text { (bandwidth } 20 \mathrm{MHz})\end{array}$ \\
\hline Symmetry & Asymmetrical and symmetrical \\
\hline \multicolumn{2}{|c|}{ Table 4: WiMAX characteristics [19] }
\end{tabular}

WiMAX configuration will be chosen to operate in the licensed $3.5 \mathrm{GHz}$ frequency band to minimize interference issues. The WiMAX system will comprise of the following discrete elements: Base Station equipment; User-side equipment (Customer Unit); and Management System.

\subsection{Cost Modeling the WiMAX System}

For capacity limited deployment scenarios it is necessary to deploy base stations with a BS to BS spacing sufficient to match the expected density of endcustomers. Data density is an excellent metric for matching capacity to market requirements. Demographic information including population, households and businesses per sq-km or sq-mi is readily available from a variety of sources for most metropolitan areas. With this information and the expected services to be offered along with an expected market penetration, data density requirements are easily calculated [20]. This process is summarized in the next figure.

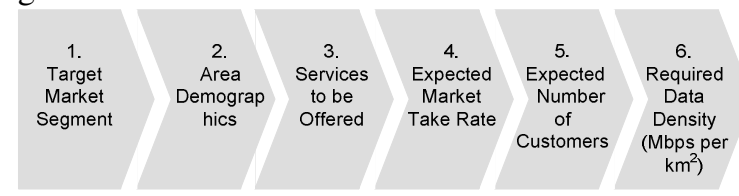

Figure 6: Determining Market Driven Capacity Requirements [20]

Base stations (towers) and base station equipment need not be installed in totality at the first year, but can be deployed over a period of time to address specific market segments or geographical areas of interest to the operator. However, in area with high number of potential subscribers, it is desirable to install a sufficient number of base stations to cover an addressable market large enough to quickly recover the fixed infrastructure cost [21].

The estimation of infrastructure cost will take into account both the capital expenditure (CAPEX) and the network running cost (OPEX). The cost elements break down into the following: Capital expenditure (CAPEX): CPE; Base station equipment cost, site buildout cost, site installation cost, etc. Operational expenditure (OPEX): annual operating, administration and maintenance cost (OAM), power consumption cost, site lease cost, transmission cost, etc. 


\subsection{WiMAX Equipment Cost}

CPE: The Customer Premises equipment consists of two main blocks: the antenna unit and the modem equipment. The CPE antenna type depends on the nonline-of-sight capabilities of the system. In a line-ofsight FWA network, the CPE antennas are highly directional and installed outdoors by a professional technician. In non-line-of-sight systems, the beamwidth of the CPE antenna is typically larger, and in the case of user-installable CPEs the antenna should be omnidirectional.

Base Station: The base station equipment, like CPE, consists of two main building blocks [22]: The antenna unit and the modulator/demodulator equipment. The antenna unit represents the outdoor part of the base station, and is composed by: antenna, a duplexer, a radio frequency (RF) low noise amplifier and a down/up converter. The BS consists of one or more radio transceivers, each of which connects to several CPEs inside a sectorized area. In the BS one directional sector antenna is required for each sector.

\section{Results}

The specific input parameters for WiMAX are grouped in equipment, coverage and housing parameters. In the equipment parameters we must define the characteristics for the base station and CPE equipment. For the coverage parameters, our tool requires the definition of the maximum distance between BS and subscribers.

Following we present the table where is calculated the necessary equipment, and the respective costs for 10 years. In the end of the table, we obtain the CAPEX, OPEX, cost per subscriber, etc. The unit costs of the several components are in a DB external.

\begin{tabular}{|c|c|}
\hline \multicolumn{2}{|c|}{ Inside Plant } \\
\hline \multicolumn{2}{|l|}{ Equipment Costs } \\
\hline $\begin{array}{l}\text { Total cost of OLT ports: only for } \\
\text { subscribers }\end{array}$ & $\begin{array}{l}=\text { Cost of OLT Ports (Unit) }{ }^{*} \text { Total } \\
\text { OLT port required for Subscribers: } 1 \\
\text { port per RT }(\mathrm{ONU})\end{array}$ \\
\hline Total cost of OLT Chassis & $\begin{array}{l}\text { = Cost of OLT_Chassis (Unit) } * \text { Total } \\
\text { OLT_Chassis required }\end{array}$ \\
\hline \multicolumn{2}{|l|}{ Installation Costs } \\
\hline OLT Ports Installation & $\begin{array}{l}=\text { cost of OLT installation (unit) } * \\
\text { Total OLT port required: } 1 \text { port per } \\
\text { Remote Terminal (ONU) }\end{array}$ \\
\hline \multicolumn{2}{|c|}{ Total Inside Plant = Equipment costs + Installation Costs } \\
\hline \multicolumn{2}{|c|}{ Outside Plant } \\
\hline \multicolumn{2}{|l|}{ Equipment Costs } \\
\hline $\begin{array}{l}\text { Total cost of ONU's: } \\
\text { FTTH: PON (Subscr home): only for } \\
\text { subsc } \\
\text { FTTcurb/Cabinet (street cabinets): } \\
\text { only HP }\end{array}$ & $\begin{array}{l}\text { = Cost of ONU equipment (unit) } * \text { Total } \\
\text { Subscribers } \\
=\text { Cost of ONU equipment (unit) } * \text { Total } \\
\text { of ONU's required }\end{array}$ \\
\hline
\end{tabular}

\begin{tabular}{|c|c|}
\hline $\begin{array}{l}\text { Total cost of Primary Split (feeder } \\
\text { plant) }\end{array}$ & $\begin{array}{l}=\text { Cost of Splitter } * \text { Total of Feeder } \\
\text { Networks }\end{array}$ \\
\hline $\begin{array}{l}\text { Total cost of Secondary Split } \\
\text { (Distrib. plant) }\end{array}$ & $\begin{array}{l}=\text { Cost of Splitter } * \text { Total of } \\
\text { Distribution Networks }\end{array}$ \\
\hline \multicolumn{2}{|l|}{ Installation Costs } \\
\hline Total ONU's Installation & $\begin{array}{l}=\text { Cost of ONU installation(unit) } * \\
\text { Number New ONUs (Total subsc) }\end{array}$ \\
\hline Total Splitters Installation & $\begin{array}{l}=\text { Cost of Splitter Installation (Unit) * } \\
\text { Total Splitters required }\end{array}$ \\
\hline \multicolumn{2}{|l|}{ Housing Costs: for all homes passed } \\
\hline $\begin{array}{l}\text { Total cabinet (Splitter enclosure) } \\
\text { costs }\end{array}$ & $\begin{array}{l}\text { = Splitter enclosure Cost (each) }{ }^{*} \text { Total } \\
\text { NEW enclosures required (Feeder and } \\
\text { Distribution) }\end{array}$ \\
\hline \multicolumn{2}{|l|}{ Cables costs: for all Homes Passed } \\
\hline Total Cable Costs: Feeder plant & $\begin{array}{l}=\text { Optical Fiber cost }(\text { Euros / Km) } \\
\text { Total length of new cable in Feeder } \\
\text { plant }(\mathrm{Km})\end{array}$ \\
\hline Total Cable Costs: Distribution plant & $\begin{array}{l}=\text { Optical Fiber cost (Euros / Km)* } \\
\text { Total length of new cable in Distribution } \\
\text { plant }(\mathrm{Km})\end{array}$ \\
\hline Total Cable Costs: Drop plant & $\begin{array}{l}\text { = Optical Fiber/ copper cost (Euros / } \\
\text { Km) * Total length of new cable in Drop } \\
\text { plant }(\mathrm{Km})\end{array}$ \\
\hline \multicolumn{2}{|l|}{ Civil Works: for all Homes passed } \\
\hline $\begin{array}{l}\text { Digging and ducting costs: Feeder } \\
\text { plant }\end{array}$ & $\begin{array}{l}=\text { Feeder Plant: Digging and ducting } \\
\text { costs }(€ / \mathrm{Km}) * \text { Total Feeder length of } \\
\text { New conduits }(\mathrm{Km})\end{array}$ \\
\hline $\begin{array}{l}\text { Digging and ducting costs: } \\
\text { distribution plant }\end{array}$ & $\begin{array}{l}=\text { Distribution Plant: Digging and } \\
\text { ducting costs (euros / } \mathrm{Km} \text { ) } * \text { Total } \\
\text { Distribution length of New conduits } \\
(\mathrm{Km})\end{array}$ \\
\hline $\begin{array}{l}\text { Digging and ducting costs: drop } \\
\text { plant }\end{array}$ & $\begin{array}{l}=\text { Distribution Plant: Digging and } \\
\text { ducting costs (euros / Km) } * \text { Total Drop } \\
\text { length of New conduits }(\mathrm{Km})\end{array}$ \\
\hline $\begin{array}{l}\text { Feeder Cable Installation costs: } \\
\text { Pulling (cable not included) }\end{array}$ & $\begin{array}{l}=\text { Cost to install Fiber }(€ / \mathrm{km}) * \text { Total } \\
\text { length of NEW cable in Feeder plant } \\
(\mathrm{Km})\end{array}$ \\
\hline $\begin{array}{l}\text { Distribution Cable Installation costs: } \\
\text { Pulling (cable not included) }\end{array}$ & $\begin{array}{l}=\text { Cost to install fiber }(€ / \mathrm{km}) * \text { Total } \\
\text { length of NEW cable in Distribution } \\
\text { plant }(\mathrm{Km})\end{array}$ \\
\hline $\begin{array}{l}\text { Drop Cable Installation costs: } \\
\text { Pulling (cable not included) }\end{array}$ & $\begin{array}{l}=\text { Cost to install fiber / copper }(€ / \mathrm{km}) \\
* \text { Total length of NEW cable in Drop } \\
\text { plant }(\mathrm{Km})\end{array}$ \\
\hline
\end{tabular}

Total Outside Plant $=$ Equipment costs + Installation Costs + Housing costs + Cable costs + Civil works

CPE

Equipment Costs

\begin{tabular}{|l|l|}
\hline Total of Fiber modem's cost & $\begin{array}{l}\text { = Cost of Fiber Modem equipment } \\
\text { (Unit) * Number of Subscribers }\end{array}$ \\
\hline Installation Costs & $\begin{array}{l}\text { = Fiber Modem installation cost (Unit) } \\
* \text { Number of Subscribers }\end{array}$ \\
\hline Total Fiber Modem's Installation & Total CPE Plant = Equipment costs + Installation Costs
\end{tabular}

Table 5: Variables used to estimate the total cost (FTTH: $\mathrm{PON}$ and FTTcurb/cabinet architectures)

\section{Base Station (for subscribers)}

\begin{tabular}{|l|l|}
\hline Equipment Costs \\
\hline $\begin{array}{l}\text { Total Cost of BS equipment } \\
\text { (including multiplexer....) }\end{array}$ & $\begin{array}{l}\text { = Number of BS required per year * } \\
\text { WiMAX_BS cost (unit) }\end{array}$ \\
\hline $\begin{array}{l}\text { Total cost of New Sectors } \\
\text { (Transceiver and antenna) }\end{array}$ & $\begin{array}{l}\text { Number of Sectors required per year * } \\
\text { WiMAX_Sector cost (unit) }\end{array}$ \\
\hline Installation Costs & $\begin{array}{l}\text { = Number of BS required per year * } \\
\text { WiMAX_BS_Installation Cost }\end{array}$ \\
\hline Total WiMAX_BS_Installation & $\begin{array}{l}\text { = Number of Sectors required per year * } \\
\text { WiMAX_Sector_Installation Cost }\end{array}$ \\
\hline Total WiMAX_Sector_Installation
\end{tabular}




\begin{tabular}{|c|c|}
\hline \multicolumn{2}{|l|}{ Housing Costs } \\
\hline Total WiMAX_SiteAquisition & $\begin{array}{l}=\text { Number of BS required per year * } \\
\text { WiMAX_SiteAquisition cost (unit) }\end{array}$ \\
\hline \multicolumn{2}{|l|}{ Civil Work Cost (for BS) } \\
\hline Total WiMAX_BS_CivilWorks & $\begin{array}{l}=\text { Number of BS required per year * } \\
\text { WiMAX_BS_CivilWorks cost (unit) }\end{array}$ \\
\hline \multicolumn{2}{|c|}{$\begin{array}{l}\text { Total Base Station cost = Equipment costs + Installation Costs + Housing } \\
\text { Costs + Civil Works }\end{array}$} \\
\hline \multicolumn{2}{|c|}{ CPE } \\
\hline \multicolumn{2}{|l|}{ Equipment Costs } \\
\hline Total Indoor CPEs cost & $\begin{array}{l}=\text { PercCpeCostOperatorWimax } * \text { Number } \\
\text { of new Indoor CPEs (per year) } * \text { Cost of } \\
\text { Indoor CPEs (Unit) }\end{array}$ \\
\hline Total Outdoor CPEs cost & $\begin{array}{l}=\text { PercCpeCostOperatorWimax } * \text { Number } \\
\text { of new Oudoor CPEs (per year) } * \text { Cost of } \\
\text { Outdoor CPEs (Unit) }\end{array}$ \\
\hline \multicolumn{2}{|l|}{ Installation Costs } \\
\hline $\begin{array}{l}\text { Total WiMAX CPE } \text { Outdoor } \\
\text { Installation }\end{array}$ & $\begin{array}{l}=\text { Number of new Oudoor CPEs (per year) } \\
\text { WiMAX CPE Outdoor Installation Cost }\end{array}$ \\
\hline \multicolumn{2}{|c|}{ Total CPE Plant= Equipment costs + Installation Costs } \\
\hline
\end{tabular}

Table 6: Variables used to estimate the total cost:WiMAX

On the basis of the previous sheets and with the definite parameters, we be able to produce several helpful results. It is calculated for each year (10 years) the several results (CAPEX, OPEX, Cumulated cash flow, Cost per subscriber, Cost per homes passed, NPV, IRR, etc.

\section{Conclusion}

This paper presents a model framework and identifies all the essential costs of building access networks for seven broadband access technologies. The work identifies three main important layers: Introduction of the general input parameters (Layer 1Scenario definition); introduction of the Specific parameters for each technology, and the $\mathrm{db}$ access (Layer 2); and the outputs production (Layer 3). This paper focuses the identification of the Specific Input Parameters because we consider one of the most important keys for the successful deployment of our tool.

The proposal tool performs a detailed comparison of the different broadband access technologies in several scenarios. Different market segments (Scenarios) have different geographical characteristics and will require different amounts of access bandwidth. These different market segments will be served by alternative access technologies that minimize overall costs. To measure the attractiveness of the several broadband access technologies, the proposal tool compares the costs, revenues, NPV, IRR, payback periods, etc. for the three scenarios along 10 periods

\section{References}

[1] O. C. Ibe, Fixed Broadband Wireless Access Networks and Services John Wiley \& Sons, Inc., 2002.
[2] J. Cornu and G. Hughes, "Digital Divide and Broadband Territorial Coverage," $e$ Europe Advisory Group,June2004

[3] H. Galperin, "Wireless Networks and Rural Development: Opportunities for Latin America," Information Technologies and International Development, vol. 2, no. 3, pp. 47-56, Mar.2005.

[4] C. Boscher, N. Hill, P. Laine, and A. Candido, "Providing Always-on Broadband Access to Under-served Areas," Alcatel Telecommunications Review,2004.

[5] L. A. Ims, A. Bhatnagar, E. Østlyngen, and K. Bozorgebrahimi, "Towards the next generation broadband network platform," Telektronikk, pp. 107-125, Apr.2004.

[6] K. Wanichkorm, "The role of fixed wireless access networks in the deployment of broadband service and competition in local telecommunications markets." Doctor of Philosophy Engineering and Public Policy, Carnegie Mellon University, 2002.

[7] J. P. Pereira and J. A. Pires, "Broadband Technologies and the Access Network," in $7^{\circ}$ CAPSI CAPSI, 2007, pp. 50-60.

[8] J. P. Pereira and J. A. Pires, "BroadBand Access technologies: Evaluation Tool," ICECE, 2007, pp. 63-73.

[9] R. Montagne, A. Causse, N. Elnegaard, D. Ryan, and L. Bråten, "Broadband access roadmap based on market assessment and technical economic analysis," Broadwan,001930, Apr.2005.

[10] C. Gomez and J. Palet, "6POWER: Business Plan Update," Information Society Technologies - European Commission,IST Project No. IST-200137613, Nov.2004.

[11] M. K. Weldon and F. Zane, "The economics of fiber to the home revisited," Bell Labs Technical Journal, vol. 8, no. 1, pp. 181-206, 2003.

[12] A. Kelic, "Networking Technology Adoption: System Dynamics Modeling of Fiber-to-the-Home." Doctor of Philosophy in Technology, Management, and Policy Massachusetts Institute of Technology, 2005.

[13] T. Smura, "Competitive Potential of WiMAX in the Broadband Access Market: A Techno-Economic Analysis," Helsinki University of Technology, 2006.

[14] T. Koonen, "Fibre to the Home/Fibre to the Premises: what, where, and when?," in Proc. IEEE 2005 2005, pp. 1-30.

[15] B. Kantner, "The FTTP battlefield: Active Ethernet vs. PON," Lightwave, pp. 1-5, Oct.2004.

[16] Corning, "Broadband Technology Overview: Optical Fiber," Corning,WP6321, June2005.

[17] K. Stordahl, "Long-term broadband technology forecasting," Telektronikk, pp. 13-31, Apr.2004.

[18] CNES, PRS, R\&S, and TBM, "Overall Broadband Satellite System Architecture and Specifications," IST IMOSAN,FP6-027457, June2006.

[19] A. Jacobsen, B. T. Olsen, R. Poff, S. Abraham, and I. Borges, "WiMAX in Backhaul and Access Networks," EUROSCOM,P1446, Feb.2005.

[20] WiMAX Forum, "WiMAX Deployment Considerations for Fixed Wireless Access in the $2.5 \mathrm{GHz}$ and $3.5 \mathrm{GHz}$ Licensed Bands,"May2005.

[21] WiMAX Forum, "Business Case Models for Fixed Broadband Wireless Access based on WiMAX Technology and the 802.16 Standard," WiMAX Forum,Oct.2004.

[22] EURESCOM, "Techno-economic analysis of integrated wireless-optical networks," EURESCOM,P816-PF, 2000. 